Some parallels can be drawn with certain hereditary tumour syndromes such as multiple endocrine neoplasia. Both are characterised by a focal or multifocal pattern of distribution, abnormal cellular proliferation, and a genetic component. The hereditary tumour syndromes are thought to result from an inherited mutation in one allele of a tumour suppresser gene and an acquired mutation in the other allele. ${ }^{4}$

Almost 20 years have elapsed since Rebel first noted "virus-like" particles in pagetic osteoclasts, but the identity of these structures remains unclear and they are not specific to Paget's disease. Immunohistochemical and in situ hybridisation studies have yielded conflicting results, since at different times evidence has been presented to suggest that antigens or nucleic acids from measles virus, respiratory syncytial virus, or canine distemper virus might be present in pagetic tissue or cultured cells ${ }^{67}$ but no virus has been isolated from affected tissue. Several groups have now used the polymerase chain reaction to try to recover paramyxovirus sequences from pagetic bone. Colleagues and I found no evidence of measles virus, canine distemper virus, respiratory syncytial virus, or related paramyxoviruses in RNA extracted from pagetic tissue, ${ }^{8}$ and $M$ Birch et al recently reported similar findings. ${ }^{9}$ Though canine distemper virus transcripts (and in one case measles virus also) have been isolated from pagetic tissue, ${ }^{10}$ these data must be interpreted with caution in view of the possibility of external contamination, since the same group had previously worked with probes to both viruses during earlier in situ hybridisation studies. ${ }^{7}$ Finally, D Roodman et al recently reported finding measles virus transcripts in cells derived from cultured pagetic bone. ${ }^{9}$ These contradictory data could perhaps be explained by different viruses having a role in different geographical areas.

The powerful molecular techniques now available should soon result in great advances in our understanding of Paget's disease. ${ }^{7-10}$ An important immediate issue is to confirm whether paramyxovirus sequences can consistently be isolated from pagetic tissue and, if so, to determine whether their presence is disease specific.

STUART H RALSTON

Department of Medicine and Therapeutics,

Aberdeen AB9 2ZD

Smith R. Paget's disease of bone, $B M 7$ 1992;305:1379-80. (5 December.)

2 Siris ES, Ottman R, Flaster E, Kelsey Л. Familial aggregation of Paget's disease of bone. $\mathcal{F}$ Bone Miner Res 1992;6:495-500.

3 Gardner MJ, Guyer PB, Barker DJP. Radiological prevalence of Paget's disease of bone in British migrants to Australia. BMJ 1978;i:1655-7.

Knudson AG. Hereditary cancer, oncogenes and anti-oncogenes. Cancer Res 1985;45:1437-43.

Kanis JA. Pathophysiology and treatment of Paget's disease of bone. London: Martin Dunitz, 1992:1-293.

Mills BG, Singer FR. Critical evaluation of viral antigen data in Paget's disease of bone. Clin Orhop 1987;217:16-25.

7 Gordon MT, Anderson DC, Sharpe PT. Canine distemper virus localised in bone cells of patients with Paget's disease. Bone 1991;12:195-201.

8 Ralston SH, DiGiovine FS, Gallacher SJ, Boyle IT, Duff GW. Failure to detect paramyxovirus sequences in Paget's disease of bone using the polymerase chain reaction. $\mathcal{f}$ Bone Miner Res 1991;6:1243-8.

9 Selby $P$, ed. Proceedings of the first international symposium on Paget's disease of bone. Semin Arthritis Rheum (in press).

10 Gordon MT, Mee AP, Anderson DC, Sharpe PT. Canine distemper transcripts sequenced from pagetic bone. Bone Miner 1992;19:159-74

EDIToR,-Roger Smith underestimates the contribution that biochemical markers of bone resorption can make to the diagnosis and monitoring of Paget's disease.' Though urinary hydroxyproline and alkaline phosphatase are useful markers of bone resorption and synthesis, respectively, they are rather non-specific. Though no good new assays exist to supplement assays of alkaline phosphatase to assess bone formation, more specific markers are becoming available for bone resorp- tion. Pyridinoline (also known as hydroxylysyl pyridinoline) and deoxypyrolidine (also known as lysyl-proline) are not further metabolised, thus providing a better index of resorption than hydroxyproline, which also has the disadvantage that it is found in skin as well as bone.

Pyridinoline and deoxypyrolidine are found in collagens I, II, III, and IX, so both are found in extracellular matrix collagen crosslinks, while deoxypyrolidine is more common than pyridinoline in type I bone collagen crosslinks: the ratio of pyridinoline:deoxypyrolidine is $3.5: 1$ in bone collagen as opposed to $10: 1$ in other collagens. ${ }^{23}$ Released as a result of bone degradation, these markers can be measured either singly or together (to derive a pyridinoline:deoxypyrolidine ratio) by high performance liquid chromatography with fluorescene detection in 24 hour urine specimens and correlate well with rates of bone resorption.

Department of Chemical Pathology,

Charing Cross and Westminster Medical School,

Westminster Hospital

London SWIP 2AR

Smith R. Paget's disease of bone. BMF 1992;305:1379-80. 5 December.)

2 Eyre D. New markers of bone resorption. 7 Clin Endocrinol Metab 1992;74:470A-C.

3 Demers LM. New biochemical marker for bone disease: is it a breakthrough? Clin Chem 1992;38:2169-70.

\section{Getting it right}

EDITOR,-Helen Zeitlin is wrong in claiming that my article about her reinstatement was unjust and incorrect.' She has misinterpreted an indirect quote from evidence given on behalf of the health authority as a statement of fact by me. She knows that I am well aware that the 20 complaints referred to in that evidence were "unsubstantiated and had not even materialised," since I have covered her case in detail since the beginning. In the paragraph of which she complains I was briefly putting each side's case as outlined to the inquiry. Surely she is not suggesting that only her side of the case should have been put.

London NW1 7EG

CLARE DYER

1 Zeitlin H. Whistle blowing. BMJ 1993;306:210. (16 January.)

\section{Part time working and job sharing}

EDITOR,-J E Morrell and A J Roberts warn of the difficulties of part time senior registrar training. ${ }^{\prime}$ These are well illustrated by my own case. Working full time, I completed my general professional training, gained the MRCP, and undertook research. When I first applied for part time training in September 1984 I was interviewed within two weeks of the birth of my first child. There was only one post for part time senior registrar training in general medicine in the whole country, and I was not successful.

The next year only one post was available, and again I failed. My research post had been extended by my working part time, but in 1986 funding ran out. I had an MD and had had several articles published, and I was totally demoralised, feeling better qualified than some colleagues in full time senior registrar posts. Fortunately, the postgraduate dean organised a part time medical registrar post. In 1987 my application was successful, although there was only one post. I understand that the next year three posts were available.

Manpower approval was granted in January 1987. The educational programme was submitted, but the college did not visit until October. Its report was sent to my supervisors in February 1988, and after a few minor changes the college's final approval was received in May. Wessex region would not recognise me as a senior registrar until the college's approval had been received. I had two manpower extensions. The senior registra contract arrived dated May 1988, and a six month battle ensued to get it backdated to January 1987 . I was not a pioneer of part time senior registrar training in Wessex: several people were already in post.

Success in part time senior registrar training requires tremendous personal commitment, a sympathetic supervisor, and a helpful postgraduate dean. I was fortunate, yet I can recall that during my earliest discussions there was considerable concern about how a consultant appointment committee might view part time training. In my case, I am pleased to say, it was regarded in the same light as full time training. As Morrell and Roberts say, the experience is an invaluable education for the battles in the NHS as a consultant.

East Herts NHS Trust,

WENDY GATLING

Welwyn Garden City AL7 4HQ

1 Morrell JE, Roberts AJ. How to make an application for part time senior registrar training. BMF 1992;305:1411-3. (5 December.)

EDITOR,-Graham Thornicroft and Geraldine Strathdee discuss their experience of sharing a consultant post.' We have job shared for two years in several senior house officer posts in different specialties as part of our own scheme for vocational training for general practice. We have found it to be the ideal way of combining pursuit of a career in medicine with bringing up a family.

There is considerable difficulty in getting shortlisted when job sharing, and consequently we have found that job applications need meticulous planning. We submit our CVs with a joint covering letter explaining about job sharing, our reasons for choosing it, and how we would apply it to the advertised post. Most consultants have never experienced job sharing and have preconceived worries about its possible ramifications. We therefore believe that it is important to meet as many as possible, if not all, of the consultants before shortlisting, preferably together for a show of unity. Before the interview it is important to discuss the duties of the post with the present incumbents, paying particular attention to rotas and the timetabling of commitments such as ward rounds, on take days, and postgraduate meetings. It is then possible to decide how to split the hours of the job optimally while still maintaining as much continuity as possible.

We have always been interviewed simultaneously, which can be advantageous: over the years we have worked out quite a double act. Questioning invariably centres on our domestic arrangements rather than our abilities: we both have young children and share a nanny. For holidays we fall in with the wishes of particular consultants. It is generally mutually convenient if we take our holidays together as a block (it also enables us to give the nanny time off). Finally, interviewers are often hesitant to broach the question of one partner wishing to resign, so at interview we raise the issue and offer reassurance that should it ever occur the remaining partner would either also resign or take on the post full time.

Like Thornicroft and Strathdee, we emphasise the importance of trust and respect between the partners. We believe that our strength comes from our friendship and having similar priorities in life. Job sharing is not for the faint hearted: it demands complete commitment. To work effectively it needs the right partners and considerable organisation and communication. It is still a novel concept, and potential job sharers should be aware that they will be breaking new ground and that their 